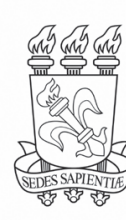

\title{
Artigos
}

\section{Hydrogel and irrigation frequencies in survival, growth and gas exchanges in Eucalyptus urograndis}

\author{
Hidrogel e frequências de irrigação na sobrevivência, crescimento e \\ trocas gasosas em Eucalyptus urograndis
}

\author{
Dionéia Felippe ${ }^{\top}$ \\ Marcio Carlos Navroski' ${ }^{\oplus}$ \\ Jean Alberto Sampietro ${ }^{\oplus}$ \\ Clenilso Sehnen Mota" $\odot$ \\ Mariane de Oliveira Pereira' ${ }^{\oplus}$ \\ Jackson Adriano Albuquerque ${ }^{\odot}$ \\ Ramon Silveira de Andrade ${ }^{\oplus}$ \\ Carolina Moraes ${ }^{\odot}$
}

Universidade do Estado de Santa Catarina, Lages, SC, Brazil

"Instituto Federal Catarinense, Rio do Sul, SC, Brazil

\begin{abstract}
The objective of this study was to evaluate the effect of the hydrogel on the planting of clonal Eucalyptus urograndis seedlings in pots, related to different water management, to provide information about the hydrogel use efficiency. The experiment was carried out in a forest nursery in a factorial scheme, as factor " $\mathrm{A}$ " referred to the absence and presence of hydrogel and factor " $\mathrm{B}$ " to water management ( 0 irrigation only at planting, 1 - daily, 4 - every 4 days, and 8 - every 8 days). Evaluations of the water stress symptomatology, morphological characteristics, chlorophyll content, soil water content, gas exchange, increase in diameter and height, and dry biomass were performed. The hydrogel provided an increase in water content in the soil and a delay in the symptoms of water stress, increasing the survival rate. Water stress was a limiting factor for stomatal opening, contributing to the decrease in carbon assimilation by photosynthesis.
\end{abstract}

Keywords: Water-insoluble polymer; Intermittent irrigation; Water deficit 


\section{RESUMO}

O objetivo do trabalho foi avaliar o efeito do hidrogel no plantio de mudas clonais de Eucalyptus urograndis em vasos, relacionados com diferentes manejos hídricos, buscando fornecer informações sobre a eficiência do uso do hidrogel. O experimento foi conduzido em viveiro florestal, esquema fatorial, em que o fator " $A$ " se referiu à ausência e à presença de hidrogel e o fator " $B$ " ao manejo hídrico (irrigação somente no plantio, 8 dias, 4 dias e diariamente). Foram realizadas avaliações da sintomatologia do estresse hídrico, características morfológicas, teores de clorofila, teor de água no solo, trocas gasosas, incremento em diâmetro e altura e biomassa seca. O hidrogel proporcionou um aumento no teor de água no solo e um atraso nos sintomas de estresse hídrico, aumentando a taxa de sobrevivência. O estresse hídrico foi um fator limitante para a abertura estomática, contribuindo para a queda na assimilação de carbono pela fotossíntese.

Palavras-chave: Polímero hidrorretentor; Irrigação intermitente; Deficit hídrico

\section{INTRODUCTION}

Among the most cultivated forest species in Brazil, stands out the Eucalyptus genus, occupying 5.7 million hectares of the planted trees area, representing $72.7 \%$ of total (INDÚSTRIA BRASILEIRA DE ÁRVORES, 2017). Eucalyptus is known to be a fast grow tree genus, and for that, it has been increasing its prominence in reforestation programs. This genus is often selected due to the ease of manipulation, diversity of species, fast growth, and mainly for its wide range of industrial purposes.

The influence of environmental variables on the growth of Eucalyptus stands notorious, as the growth and development of the plants are affected by environmental factors (PFAUTSCH et al., 2016). The introduction of new species from other regions is always a process that requires studies aiming to test their adaptability and survival, as well as their economic and productivity effects (OTTO et al., 2013).

Variations in productivity of Eucalyptus are related to differences in water supply, nutrients, soil aeration and mechanical restriction to root growth. Water is considered the factor that most influences plant growth (CASTRO el al., 2017). The effect of water deficiency on plants is complex, as there are mechanisms of resistance to drought, plants can respond through various adaptive processes to water scarcity, such as through the ability to reduce water potential, allied to physiological, anatomical and morphological adaptations (NOGUEIRA; ALBUQUERQUE; SILVA, 2005). 
As a possible aid in the survival of seedlings after transplantation is the use of hydroretent polymers (hydrogels) as soil moisture conditioners, assisting mainly in the retention and availability of water for newly planted plants (MENDONÇA et al., 2013). It is important to note that the use of adequate irrigation systems is a key factor in the reduction of irrigation frequency, improving silvicultural techniques, contributing to the viability of planting throughout the year, and not becoming dependent on the climatic variations observed during the seasons (NAVROSKI et al., 2014; 2016).

The main objective of this search was to verify if the hydrogel presents a reduction possibility in the irrigation frequency of Eucalyptus seedlings, using visual characterization of wilt in seedlings submitted to water stress and the use of physiological parameters under these conditions, combining the determination of water content in the soil. In this way, this study evaluated the effect of the hydrogel on Eucalyptus urograndis planting, relating different water managements, seeking to provide information about the efficiency of hydrogel use in a controlled environment.

\section{MATERIALS AND METHODS}

The study was carried out in forest nursery of the University of Santa Catarina State, located in Lages, southern Brazil (coordinates $27^{\circ} 47^{\prime} 33^{\prime \prime S}$ and $50^{\circ} 18^{\prime} 4^{\prime \prime} \mathrm{W}$ ), with an altitude of approximately 900 meters. The experiment was conducted in a greenhouse with a $150-$ micron plastic cover, with an average temperature of $25-30^{\circ} \mathrm{C}$ and humidity between 65 and 90\%. According to the Köeppen classification, the climate of Lages/ $\mathrm{SC}$ is humid mesothermal with mild summer (temperate $\mathrm{Cfb}$ ). The average annual temperature is $15^{\circ} \mathrm{C}$ and the average annual rainfall is 1300 to $1500 \mathrm{~mm}$ (ALVARES et al., 2013). The study occurred during the end of September until the end of November 2015.

Rooted mini cuttings of Eucalyptus urograndis were purchased in a Forestry Nursery located in Anchieta-SC, with approximately 120 days. The plants were produced in polypropylene tubes with a capacity of $55 \mathrm{~cm}^{3}$, using substrate based on 
peat and pine bark. A total of $6 \mathrm{~g} \mathrm{~L}^{-1}$ of controlled release fertilizer was added to the substrate. The mini cuttings were placed to root in a greenhouse with humidity above $80 \%$ and temperature close to $28^{\circ} \mathrm{C}$ for 40 days. After this period, the seedlings were placed for another 60 days in a shade house and last 20 days in a rustification area. For the experiment, seedlings of $25 \mathrm{~cm}$ in height, $2 \mathrm{~mm}$ in stem diameter, between 4-5 pairs of leaves, reddish stem, well lignified and good phytosanitary condition were standardized.

The soil used for the filling of the polyethylene pots $(10 \mathrm{~L})$ was composed of soil collected at the depth of 0 to $50 \mathrm{~cm}$ of a clayey Humic Cambisol. (World Reference Base - WRB/FAO systems). The physical and chemical soil analysis are: $\mathrm{pH}=4.7 \mathrm{H}_{2} \mathrm{O}^{2}$; SMP Index = 4.90; $\mathrm{Ca}^{(2)}=2.2 \mathrm{cmol}_{\mathrm{c}} \mathrm{dm}^{-3} ; \mathrm{Mg}^{(2)}=1.2 \mathrm{cmol}_{\mathrm{c}} \mathrm{dm}^{-3} ; \mathrm{Al}^{(2)}=4.9 \mathrm{cmol}_{\mathrm{c}} \mathrm{dm}^{-3} ; \mathrm{P}$ Mehlich(2) $=3.7 \mathrm{mg} \mathrm{dm}^{-3} ; \mathrm{K}^{(2)}=48 \mathrm{mg} \mathrm{dm}^{-3}$; organic matter $-\mathrm{OM}=2.9 \%$; Effective $\mathrm{CEC}=$ $6.46 \mathrm{cmol}_{\mathrm{c}} \mathrm{dm}^{-3}$; CEC pH $7.0=13.1 \mathrm{cmol}_{\mathrm{c}} \mathrm{dm}^{-3}$; Base saturation = 26.8\%; Al saturation $=58 \%$; clay $=47 \%$, silte $=24 \%$ and sand $=28 \%$. The soil was homogenized in $10 \mathrm{~mm}$ sieves in order to avoid clods. No fertilization or liming was applied.

For the reduction of experimental errors, a uniform scale of a soil mass of $8 \mathrm{~kg}$ was standardized through a digital scale and water was subsequently added to the soil until it reached the field capacity, and its weight was measured. To determine the field capacity, the $\theta$-t observable curve procedure was used, according to the methodology of Casaroli and Van Lier (2008). For the transplanting, a manual hole of approximately $300 \mathrm{~cm}^{3}$ was opened in the center of each pot for the planting. The treatments were composed of four irrigation frequencies, besides the presence and absence of hydrogel. Water management for hydrogel treatment was exactly the same as that established in the absence of hydrogel treatment.

In the treatments using the hydrogel, $300 \mathrm{~mL}$ in the already hydrated form was added before the planting. The hydration occurred thirty minutes before in a dosage of $3 \mathrm{~g} \mathrm{~L}^{-1}$ of hydrogel, which was a granulated synthetic polymer of the brand Hidroplan$E B^{\circledR}$. After the opening of the hole for planting, whether or not the hydrogel was filled, 
the seedlings (former mini cuttings) were planted. After transplantation, in addition to the $1,500 \mathrm{~mL}$ to moisten the soil, $300 \mathrm{~mL}$ of water was added to each pot for the treatments without the hydrogel, in order to compensate the volume of water to be added by the polymer. For the irrigation treatments, $300 \mathrm{~mL}$ of water was used in each pot, as the water replacement was based according to the frequency determined in each treatment.

The experiment was conducted in a completely randomized design, with 8 replications (one seedling each), in a $2 \times 4$ factorial arrangement. The hydrogel factor was composed of two levels (presence and absence) and the frequency of irrigation was composed of four levels ( 0 - irrigation only at planting, 1 - daily, 4 - every 4 days and 8 - every 8 days).

\subsection{Evaluation of visual symptomatology, morphological evaluations and gas exchange}

Evaluations of the dry stress symptomatology were carried out daily until the $47^{\text {th }}$ day. For the visual symptomatology it was adopted the criterion of analysis according to Navroski et al. (2014), as the number of days in which the plant remained in each condition was noted: DWS - days without symptoms (turgid plant, visually vigorous, no evidence of water deficit; DMWS - days with mild wilt symptoms; DMS - days with moderate symptoms (permanent wilt point with darkened and curved apex); DSS days of severe wilt symptoms (dry leaves/in abscission) and DPRA - number of days the plant remained alive.

The gas exchange evaluations were performed with the aid of a LI-6400XT Portable Photosynthesis System, using in 4 replicates. The values of photosynthesis $(A)$, stomatal conductance $(g s)$, transpiration $(E)$, relation between intercellular and atmospheric concentration of $\mathrm{CO}_{2}(\mathrm{Ci} / \mathrm{Ca})$ and water use efficiency (WUE) were determined. The photosynthetically active radiation used during the measurements were $700 \mu \mathrm{mol}$ of photons $\mathrm{m}^{-2} \mathrm{~s}^{-1}$. Photosynthetically active radiation was provided by 
an artificial light source (LI-6400-40), percentage of blue light used was $10 \%$ of the total photosynthetically active radiation (PAR). The atmospheric $\mathrm{CO}_{2}$ concentration ranged from 390 to $400 \mu \mathrm{mol} \mathrm{mol} \mathrm{m}^{-1}$ during measurements. The evaluations were performed every seven days and started immediately after transplantation, always taking place between 8:00 am and 11:30 am. The same leaf was used throughout the experimental period. The evaluations were stable within 2-3 minutes when recorded by the equipment. The water use efficiency (WUE) was calculated by $\operatorname{dividing} A$ by $E$.

Biometric height and diameter evaluations were performed in two steps. In the first one, data were collected on the day of the experiment, and the last one at the end of the experimental period (47 days after implantation). The height of the plants (cm) was determined with millimeter ruler, measuring from the base to the insertion of the highest leaf. The diameter of the stem - DS $(\mathrm{mm})$ was determined with digital caliper ruler.

At the end of the experimental period (47 days), when the plants without irrigation were permanently wilted, the total biomass of the plants was manually collected by means of a destructive method. The samples were separated in root, stem and leaves and conditioned in paper bags kept in forced air circulation $\left(65 \pm 3^{\circ} \mathrm{C}\right)$ until reaching a constant mass (g). Afterwards, weighing was carried out to determine the contents of matter of the components in a precision balance $(0,01 \mathrm{~g})$. For the determination of the individual leaf area, all the leaves of each plant were collected, separately in paper bags and taken to the laboratory. The leaf area was quantified with Li-Cor leaf area integrator model LI3000A.

\subsection{Water content in soil}

In order to follow the moisture content of the vessels, it was decided to determine the initial water content of the soil, which makes it possible to monitor the soil water content during the experimental period. Before planting the cuttings, all pots were saturated and allowed to drain for two hours, then a sample of approximately 100 
grams of soil was collected in each pot, so that all the containers were analyzed. The samples were separated and packed in aluminum foil cups. The determination of the wet mass of the pots occurred at the experiment site after their collection, using a precision scale, thus avoiding water lose from the samples until the arrival at the laboratory.

After determination of the wet mass, the samples were dried in an oven. This occurred until the moment of stabilization of their masses, being later re-weighed, for which the dry mass was obtained. The monitoring of pots' weight occurred every 4 days, through a semi analytical balance, always performed before irrigation. With the obtaining of these values, through equations, the soil water content was established by the graviometric method.

\subsection{Statistical analysis}

The treatment variances were tested for homogeneity by the Bartlett test and normality by Shapiro-Wilk test. With homogeneity of variances and normality, the data was subjected to analysis of variance and with significant difference by the $\mathrm{F}$ test, the Scott-Knott test was applied at the 5\% probability level. When necessary, the data were transformed by the boxcox test. The analyzes were performed with the Sisvar statistical software (FERREIRA, 2019).

\section{RESULTS AND DISCUSSION}

\subsection{Visual symptomatology and morphological evaluations}

In relation to the symptoms of the Eucalyptus urograndis clones affected by the water deficit, there was interaction $(p=0.0001)$ between irrigation frequency and the use of the hydrogel for all variables evaluated. The polymer had influence on all classes of stress, regardless of the frequency of irrigation (Table 1). 
1576| Hydrogel and irrigation frequencies in survival ...

Table 1 - Duration of water stress symptoms in plants, in days, evaluated from planting until the $47^{\text {th }}$ day after planting Eucalyptus urograndis clones in pots, depending on the presence or absence of hydrogel and different irrigation frequency

\begin{tabular}{|c|c|c|c|c|c|c|}
\hline \multirow{2}{*}{ Variable } & \multirow{2}{*}{ Hydrogel } & \multicolumn{4}{|c|}{ Irrigation Frequency } & \multirow{2}{*}{ Average } \\
\hline & & planting (0) & 8 days & 4 days & daily (1) & \\
\hline & \multicolumn{6}{|c|}{ Appearance of stress symptoms (days) } \\
\hline \multirow{3}{*}{$\begin{array}{l}\text { DWS ** } \\
\text { CV\%। 2,6 }\end{array}$} & Presence & $16.7(2.0) \| \mathrm{Da}$ * & $38.0(0.5) \mathrm{Ba}$ & 44.0 (1.0) Ba & $47.0(0) \mathrm{Aa}$ & 36.4 \\
\hline & Absence & $15.4(1.5) \mathrm{Cb}$ & 35.0 (1.5) Ba & $42.0(1.5) \mathrm{Ba}$ & $47.0(0) \mathrm{Aa}$ & 34.8 \\
\hline & Average & 16.0 & 36.5 & 43.0 & 47.0 & \\
\hline \multirow{3}{*}{$\begin{array}{l}\text { DMWS } \\
\text { CV\% 4,0 }\end{array}$} & Presence & 24.7 (3.5) Ba & $41.0(2.0) \mathrm{Aa}$ & $47.0(0) \mathrm{Aa}$ & $47.0(0) \mathrm{Aa}$ & 39.9 \\
\hline & Absence & $19.2(4.5) \mathrm{Bb}$ & 39.0 (3.5) Aa & $47.0(0) \mathrm{Aa}$ & $47.0(0) \mathrm{Aa}$ & 38.0 \\
\hline & Average & 21.9 & 40.0 & 47.0 & 47.0 & \\
\hline \multirow{3}{*}{$\begin{array}{l}\text { DMS } \\
\text { CV\% 3,3 }\end{array}$} & Presence & 30.0 Ba (3.5) & $47.0(0) \mathrm{Aa}$ & $47.0(0) \mathrm{Aa}$ & $47.0(0) \mathrm{Aa}$ & 42.7 \\
\hline & Absence & $24.0 \mathrm{Bb}(4.0)$ & $47.0(0) \mathrm{Aa}$ & $47.0(0) \mathrm{Aa}$ & $47.0(0) \mathrm{Aa}$ & 41.2 \\
\hline & Average & 27.2 & 47.0 & 47.0 & 47.0 & \\
\hline \multirow{3}{*}{$\begin{array}{l}\text { DSS } \\
\text { CV\% 3,9 }\end{array}$} & Presence & $36.2(3.0) \mathrm{Ba}$ & $47.0(0) \mathrm{Aa}$ & $47.0(0) \mathrm{Aa}$ & $47.0(0) \mathrm{Aa}$ & 44.3 \\
\hline & Absence & $31.3(4.5) \mathrm{Bb}$ & $47.0(0) \mathrm{Aa}$ & $47.0(0) \mathrm{Aa}$ & $47.0(0) \mathrm{Aa}$ & 43.1 \\
\hline & Average & 33.8 & 47.0 & 47.0 & 47.0 & \\
\hline \multirow{4}{*}{$\begin{array}{l}\text { DPRA } \\
\text { CV\% 3,9 }\end{array}$} & Presence & $38.2(4.5) \mathrm{Ba}$ & $47.0(0) \mathrm{Aa}$ & $47.0(0) \mathrm{Aa}$ & $47.0(0) \mathrm{Aa}$ & 44.8 \\
\hline & Absence & $33.3(5.0) \mathrm{Bb}$ & $47.0(0) \mathrm{Aa}$ & $47.0(0) \mathrm{Aa}$ & $47.0(0) \mathrm{Aa}$ & 43.5 \\
\hline & Average & 35.7 & 47.0 & 47.0 & 47.0 & \\
\hline & & \multicolumn{5}{|c|}{ Morphological variables } \\
\hline \multirow{3}{*}{$\begin{array}{l}\text { DS (mm) } \\
\text { CV\% 9,7 }\end{array}$} & Presence & $0.77(0.31)$ & $0.97(0.22)$ & $1.77(0.39)$ & $3.13(0.45)$ & $1.66 \mathrm{a}$ \\
\hline & Absence & $0.73(0.27)$ & $0.78(0.18)$ & $1.56(0.34)$ & $2.59(0.51)$ & $1.41 \mathrm{~b}$ \\
\hline & Average & $0.75 \mathrm{C}$ & $0.87 \mathrm{C}$ & 1.66 B & $2.86 \mathrm{~A}$ & \\
\hline \multirow{3}{*}{$\begin{array}{l}\mathrm{IH}(\mathrm{cm}) \\
\text { CV\% 12,5 }\end{array}$} & Presence & $6.60(1.4)$ & $7.80(1.7)$ & $9.10(2.1)$ & $14.8(2.3)$ & 9.57 a \\
\hline & Absence & $5.38(1.8)$ & $5.16(1.6)$ & 7.98 (1.9) & $9.50(2.0)$ & $7.00 \mathrm{~b}$ \\
\hline & Average & $5.99 \mathrm{C}$ & $6.48 \mathrm{C}$ & $8.54 \mathrm{~B}$ & $12.15 \mathrm{~A}$ & \\
\hline \multirow{3}{*}{$\begin{array}{l}\text { DLB (g) } \\
\text { CV\% 9,2 }\end{array}$} & Presence & $1.71(0.32) \mathrm{Ca}$ & $2.30(0.29) \mathrm{Ca}$ & $4.92(0.64) \mathrm{Ba}$ & 5.81(0.53) Aa & 3.68 \\
\hline & Absence & $1.62(0.23) \mathrm{Ca}$ & $2.08(0.22) \mathrm{Cb}$ & $3,71(0.52) \mathrm{Bb}$ & 5.79(0.67) Aa & 3.3 \\
\hline & Average & 1.67 & 2.19 & 4.31 & 5.8 & \\
\hline \multirow{3}{*}{$\begin{array}{l}\text { DRB (g) } \\
\text { CV\% 15,2 }\end{array}$} & Presence & $1.92(0.45)$ & $2.01(0.34)$ & $3.21(1.23)$ & $5.56(2.02)$ & 3.17 \\
\hline & Absence & $1.86(0.67)$ & $2.25(0.29)$ & $3.13(1.34)$ & $4.32(1.94)$ & 2.89 \\
\hline & Average & $1.89 \mathrm{C}$ & $2.13 \mathrm{C}$ & $3.17 \mathrm{~B}$ & $4.94 \mathrm{~A}$ & \\
\hline \multirow{3}{*}{$\begin{array}{l}\text { DSB (g) } \\
\text { CV\% 9,7 }\end{array}$} & Presence & $1.72(0.32)$ & $2.19(0.34)$ & $3.37(0.94)$ & $4.10(1.43)$ & 2.87 \\
\hline & Absence & $1.50(0.21)$ & $2.05(0.49)$ & $2.87(0.73)$ & $2.90(1.23)$ & 2.33 \\
\hline & Average & $1.61 \mathrm{C}$ & $2.12 \mathrm{C}$ & $3.17 \mathrm{~B}$ & $3.50 \mathrm{~A}$ & \\
\hline
\end{tabular}

To be continued ... 
Table 1 - Conclusion

\begin{tabular}{|c|c|c|c|c|c|c|}
\hline \multirow{2}{*}{ Variable } & \multirow{2}{*}{ Hydrogel } & \multicolumn{4}{|c|}{ Irrigation Frequency } & \multirow{2}{*}{ Average } \\
\hline & & planting (0) & 8 days & 4 days & daily (1) & \\
\hline & & \multicolumn{5}{|c|}{ morphological variables } \\
\hline \multirow{3}{*}{$\begin{array}{l}\text { DTB (g) } \\
\text { CV\% 14,2 }\end{array}$} & Presence & $6.40(1.33)$ & $7.10(1.44)$ & $10.91(3.42)$ & $16.20(3.97)$ & 10.16 \\
\hline & Absence & $4.00(0.98)$ & $6.74(0.97)$ & $12.44(4.11)$ & $12.44(4.13)$ & 8.30 \\
\hline & Average & $5.20 \mathrm{D}$ & $6.74 \mathrm{C}$ & $10.65 \mathrm{~B}$ & $14.32 \mathrm{~A}$ & \\
\hline \multirow{3}{*}{$\begin{array}{l}\text { LA }\left(\mathrm{cm}^{2}\right) \\
\text { CV\% } 14,8\end{array}$} & Presence & $189.7(54)$ & $294.2(75)$ & $662.1(121)$ & $796.3(132)$ & $485.5 \mathrm{a}$ \\
\hline & Absence & $132.7(45)$ & $233.4(69)$ & $635.5(99)$ & $781.8(143)$ & $436.1 \mathrm{~b}$ \\
\hline & Average & $161.2 \mathrm{C}$ & $263.8 \mathrm{~B}$ & $636.5 \mathrm{~A}$ & $781.8 \mathrm{~A}$ & \\
\hline
\end{tabular}

Source: Authors (2017)

In where: * Averages followed by the same capital letter in the row and lowercase in the column do not differ by Scott-Knott's test, $5 \%$ probability of error. ** DWS - days without symptoms; DMWS - days with mild wilt symptoms; DMS - days with moderate symptoms; DSS - days of severe wilt symptoms; DPRA - days the plant remained alive; DS - increase in diameter of the stem ( $\mathrm{mm}) ; \mathrm{IH}$ - increase in height (cm); DLB - dry leaf biomass (g); DRB - dry root biomass (g); DSB - dry stem biomass (g); DTB dry total biomass $(\mathrm{g})$; LA - leaf area $\left(\mathrm{cm}^{2}\right)$; ' - coefficient of variation; " - standard deviation.

For classification on DWS the presence of hydrogel was efficient only at planting. The DMWS had a delay when the hydrogel was used at the frequency of irrigation at planting. The use of the hydrogel provided a reduction of 5 days in the mild wilt symptoms. For treatments in which irrigation was performed, there was no difference. For the DMS, DSS and DPRA, there was a behavior similar to the mild symptom, characterized by a delay in stress when the hydrogel was used only in the planting. This difference in the use of the hydrogel was not observed in the other irrigation frequencies. In both (presence and absence) of the polymer, the treatments that received irrigations (every day, every 4 and 8 days) did not verify mortality of the plants until the 47th day of evaluation, only specific symptoms of wilt.

Using this information for field planting, it can be assumed that in cases where irrigation occurs frequently, or in cases where rainfall frequency is higher, the use of the polymer could be ruled out (NAVROSKI et al., 2015). However, under less frequent rainfall conditions, or by making irrigations more spaced, the use of the polymer may be recommended. 
In the implantation of Eucalyptus forests, it is generally observed that the most critical period for loss of seedlings due to lack of water is in the first 20 days, when the plant is being established and with a root system still in formation (FERNÁNDEZ; TAPIAS; ALESSEO, 2010). The first physiological consequence for plants subjected to water stress is the reduction or interruption of growth rates, due to the reduction in cell differentiation, influenced by water deficiency. The water deficit can directly affect the growth in diameter, height, leaf area and consequently biomass as observed in the treatments with less frequency of irrigation and no use of hydrogel. In these cases, there is a reduction in cell expansion and cell wall formation and, indirectly, a reduction in the availability of carbohydrates or influence the production of growth regulators (GONÇALVES; PASSOS, 2000). It is also important to highlight that the largest root biomass was observed in plants with hydrogel.

In the evaluation of the number of days the plants remained alive, it was noticed that the use of the hydrogel caused an increase of approximately 5 days. This result may indicate that the use of the polymer could imply the reduction of replanting resulting in more homogeneous stands and cost reduction. In this sense, Lopes et al. (2010) observed that hydrogel delayed the symptoms of water stress in Eucalyptus urograndis, increasing survival. According to the authors, the hydrogel allowed the plants to remain alive without symptoms of lack of water for up to 20 days, up to seven days longer than in the absence of the same in the planting pits.

Similar results to those found in this study were also found by Buzetto, Bizon and Seixas (2002), in which studying the efficiency of the polymer in the water supply to Eucalyptus urophylla. The polymer retained irrigation water for a longer period, making it available gradually to the plants, which resulted in a decrease of the mortality of seedlings cultivated with the polymer. In the same sense, beneficial effects of the hydrogel (prolonged tree survival compared to the controls) were found in works by Agaba et al. (2010) with Eucalyptus grandis, Eucalyptus citriodora, Pinus caribaea, Araucaria cunninghamii, Melia volkensii, Grevillea robusta, Azadirachta indica, Maesopsis 
eminii and Terminalia superba. Furthermore, Zonta et al. (2009) with Coffea canephora, in which they reported that when incorporated into the post-planting substrate the hydrogel favored seedling growth.

For the increase in diameter of the stem - $\mathrm{mm}$ (DS) and increment of height - $\mathrm{cm}$ (IH) significant effects were observed in the isolated factors (hydrogel and the irrigation frequencies). The DS and IH increased as the irrigation frequency enhanced. The plants that received irrigation daily presented between two to three times greater growth than the moistened ones only in the planting or every 8 days. The use of hydrogel also caused a greater increase, in average among all the frequencies.

When evaluating the biomass produced by Eucalyptus urograndis clones, 47 days after the planting, the results obtained by variables analyzed, such as root dry biomass, dry stem biomass and total dry biomass, showed no interaction between the use of hydrogel with irrigation frequencies ( $p>0.05$ ). However, there was a significant effect for the isolated form factors. For the leaf dry biomass (DLB) there was a significant interaction between hydrogel use and irrigation frequencies $(p<0.05)$.

For the DLB variable, it was observed that as water availability decreased, both in the presence and in the absence of hydrogel, the leaf biomass significantly decreased. In general, the use of hydrogel, in the frequency of irrigation every day, provided higher values of dry matter accumulated in the leaves, which did not differ statistically from the absence (Table 1). Regarding DRB, the plants that received irrigation every day, presented higher averages, differing from the other frequencies. The frequency of irrigation every 4 days also showed good results when compared to the lower frequencies. The biomass results of the stem (DSB), and consequently for DTB showed similar results to those of the root, that the higher the frequency of irrigation, the greater the biomass production of the plants. These results prove the great importance of water for crops, that according to Kerbauy (2009) of all the resources that plants need to grow and function, water is the most abundant and, at the same time, often the most limiting. In this sense, irrigation practice reflects the fact that water is a key resource that limits the productivity of forest plantations. 
The leaf area $-\mathrm{cm}^{2}$ (LA) varied according to the presence and absence of the polymer, as the presence obtained the highest average in relation to the absence. For irrigation frequencies analysis of variance showed a statistical difference between the highest frequencies and the lowest frequencies. Irrigations every day and every 4 days, presented the highest averages, differing from the irrigation only at planting and every 8 days. This difference in leaf area between the frequency differences reflects the importance of water availability for crop productivity, especially in forest plantations. Many morphological characteristics of plants are genetically determined, but others, such as leaf size, can be strongly influenced by the climate conditions in which they are inserted. The limitation of the leaf area can be considered the first line of defense against water deficiency (CHAVES et al., 2004).

\subsection{Soil water content}

In general, soil moisture values varied according to the frequency of irrigation. The soil water content increased when the polymer was used, presenting higher values when compared to its absence, which may be closely related to the presence of the hydrogel as a conditioning of the soil moisture. Regardless of the frequency used to the presence of the hydrogel, it maintained the soil with the highest amount of water (Figure 1). The frequencies of 0 (planting only) and 8 days (Figure $1 \mathrm{a}$ and $1 \mathrm{~b}$ ) presented more pronounced curves in relation to the others, and therefore, a decreasing tendency in the loss of water is inferred as the frequency of irrigation decreases. Also, it is verified that the variations in the soil water content throughout the experiment were higher when the polymer was not used.

When the irrigation occurred only at planting (Figure 1a), there was a delay in the days when the visual symptoms of the evaluated water deficit appeared in the presence of the hydrogel. The mild wilt symptoms (DMWS) appeared approximately 25 days after planting, when soil water content reached $10 \%$. When compared to its 
absence, this symptom appeared five days before with approximately $9 \%$ humidity. The presence of moderate wilt symptoms (DMS) in the presence of hydrogel occurred at 30 days after planting when the water content was $7.5 \%$ and in the absence of water at 24 days after planting with a humidity of $9 \%$.

Figure 1 - Soil water content related to the visual symptomatology of water deficit in Eucalyptus urograndis clones in function of soil water content relationship between of irrigation and presence or absence of hydrogel. a) irrigation only at planting; b) irrigation every 8 days; c) Irrigation every 4 days and d) irrigation every day

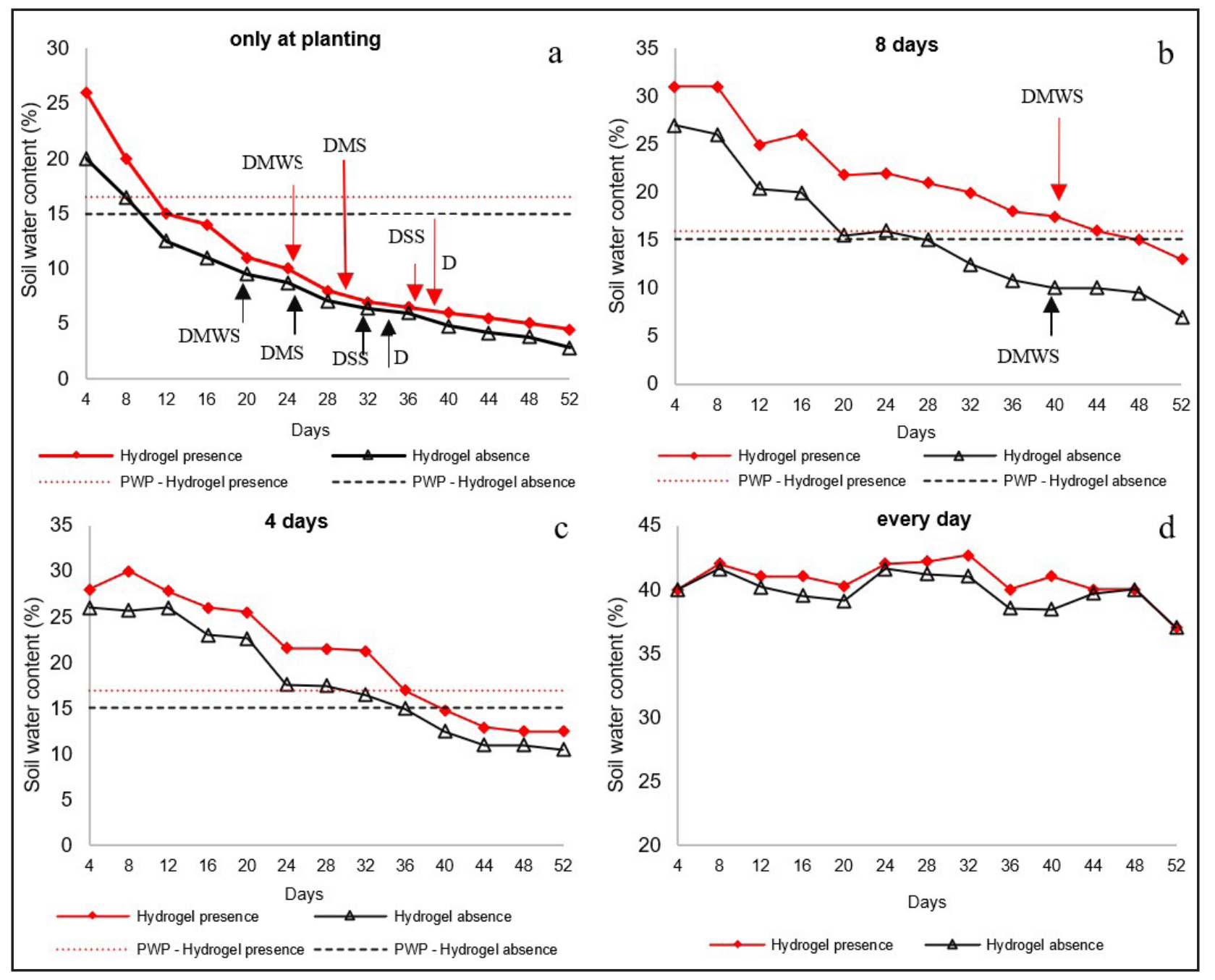

Source: Authors (2017)

In where: DMWS: mild symptoms of wilt, DMS: moderate symptoms of wilt. DSS: severe symptoms of wilt and D: dead plant. PWP - permanent wilt point. 
Considering the severe symptoms of wilt (DSS), it was observed that in the same way as the other evaluated symptoms. In the presence of hydrogel there was a delay of approximately five days in the appearance of these symptoms, occurring when the water content reached $6.5 \%$ (36 days after planting). In the absence, this symptom occurred at 31 days and at a soil water content of $7 \%$. When the water retention polymer was used, it was verified that the death of the plants occurred approximately 38 days after planting when the soil water content reached $6.3 \%$. With the non-use of hydrogel, these symptoms were observed at 33 days with $6.3 \%$ humidity.

For the 8 days frequency (Figure $1 \mathrm{~b}$ ), the onset of mild symptoms (DMWS) occurred two days later in the presence of the hydrogel. For the other irrigation frequencies, there were no symptoms of wilt. Water content in soil was always higher in the presence of the hydrogel at lower irrigation frequencies (only at planting, 8 and 4 days). This higher soil water content delayed the onset of stress symptoms in plants. There was no difference in water content in soil when irrigation was performed every day (Figure 1d), with a content close to $40 \%$ throughout the evaluations.

In general, the presence of the hydrogel promoted greater humidity. The onset of symptoms occurred when soil volumetric moisture exceeded the PWP - permanent wilt point (15.7\%), whereas in the absence of symptoms appeared before reaching PWP, which in this condition was 15\%. In the same sense, Felippe et al. (2016) state that hydrogel can be used to increase water storage capacity, minimizing the problems associated with irregular or deficient availability of water and poor structuring, being an alternative for low water availability in the ground. The increase in soil water storage capacity was also reported by Mendonça et al. (2013). The treatment of $4 \mathrm{~g} \mathrm{pot}^{-1}(8 \mathrm{~L})$ increased the storage capacity of water in the soil in relation to the control by $12 \%$, while, applying double the product $\left(8 \mathrm{~g} \mathrm{pot}^{-1}\right)$, the increase in relation to the control was $13 \%$. 


\subsection{Gas exchange}

In overall, the plants were affected by the irrigation frequencies, easily seen in the photosynthetic rate $-A-\left(\mu \mathrm{mol} \mathrm{m}{ }^{-2} \mathrm{~s}^{-1}\right)$ (Figure $\left.2 \mathrm{a}\right)$. From the planting until the $14^{\text {th }}$ day, the photosynthesis showed an increase of both in the absence and in the presence of the polymer, with no statistical difference between the treatments. During this period, water was not the limiting factor since there was enough soil water content in all treatments. The differences between irrigation frequencies were observed from the $21^{\text {st }}$ day after planting, both in the treatments with the presence or absence of the polymer, thus occurring a rapid decrease of the photosynthetic rate. It should be noted that in this period (21 days) the plants that received irrigation only at planting with the presence of hydrogel already exhibited mild wilt symptoms, while in the absence of the polymer, mild and moderate wilt symptoms have already occurred. Among all frequencies, the highest photosynthetic rate was observed in the presence of hydrogel at 21 days after planting when irrigation occurred every day. In the absence of hydrogel the reduction was more pronounced reaching zero at 46 days.

Water deficit stress is produced both by water limitation in the soil and by more aerial transpiration than the roots can absorb. These processes are influenced by environmental factors and plant characteristics (KLIPPEL et al., 2014). Lawlor (2002) states that during water stress, photosynthetic metabolism is more sensitive to changes in cellular water content in some types of plants than in others, although the causes of these differences are still poorly understood. Some plants show decreases in the photosynthetic rate in a parallel and linear manner to the decrease in the relative water content, while others show a decrease in the photosynthetic rate only when the decrease in water content exceeds between 20 to $30 \%$.

Analyzing the transpiration data $-E-\left(\mathrm{mmol} \mathrm{m}^{-2} \mathrm{~s}^{-1}\right)$ (Figure $\left.2 \mathrm{~b}\right)$, it was verified that there was an independent variation of the irrigation frequency used. In general, there was an increase in perspiration rate up to the $14^{\text {th }}$ day. After this period there was reduction, except when irrigation was performed more frequently. When irrigation occurred only at planting and every 8 days, the transpiration presented the lowest 
values, decreasing rapidly. In the presence of the hydrogel, the transpiration presented higher rates than in the absence of the polymer.

In the presence of the hydrogel, the transpiration $(E)$ presented higher rates than in the absence of the polymer. This reduction in transpiration is because water deficit was responsible for decreasing leaf transpiration due to stomatal closure. Since the opening of stomata depends on the degree of water saturation of stomatal cells, there may be great restriction of transpiration when the water deficit in the plant is very large. The partial closure of the stomata is a strategy of plant tolerance to water deficiency because it reduces transpiration rate, maintains leaf water content, reduces the risk of dehydration and eventual death by desiccation (NASCIMENTO et al., 2011). In this work the results showed that, with a decline in the relative water content in the soil, i.e., as the frequency of irrigation decreases, there is also a decrease in the rate of transpiration.

The decline of stomatal conductance in the Eucalyptus urograndis clone used in the present study coincides with the behavior observed in irrigated and nonirrigated Eucalyptus sp. under field conditions, observed by Otto et al. (2013). This demonstrates that Eucalyptus exerts efficient stomatal control under conditions of low water availability in the soil.

The water use efficiency - WUE ( $\left.\mu \mathrm{mol} \mathrm{CO}^{2} \mu \mathrm{mol} \mathrm{H}_{2} \mathrm{O}^{-1}\right)$ (Figure $2 \mathrm{~d}$ ) also obtained a behavior close as transpiration. When irrigation occurred only at planting, water use was similar until $14^{\text {th }}$, and there was no statistical difference between treatments regardless of presence or absence of the polymer. From the $14^{\text {th }}$ to the $35^{\text {th }}$ day in the presence of hydrogel, a higher WUE was detected. However, a more efficient use of water in the 35th day treatment did not use the polymer. It is likely that this efficiency, in this case, is linked to the lower rate of plant transpiration. The ecological advantage that plants obtain when regulating transpiration is to maintain a linear relation with the WUE, thus optimizing the gas exchanges. The efficiency of water use for crop productivity depends on the species, stage of development, plant density, environmental conditions, and above all, water availability and air evaporation capacity (LARCHER, 2006). 
Figure 2 - a) photosynthetic rate $(A)$; b) transpiration (E); c) stomatal conductance $(\mathrm{g})$; d) water use efficiency (WUE) and e) relation between the intercellular and atmospheric concentrations of $\mathrm{CO}_{2}(\mathrm{Ci} / \mathrm{Ca})$ in Eucalyptus urograndis clone as a function of the presence or absence of hydrogel submitted to different irrigation frequencies

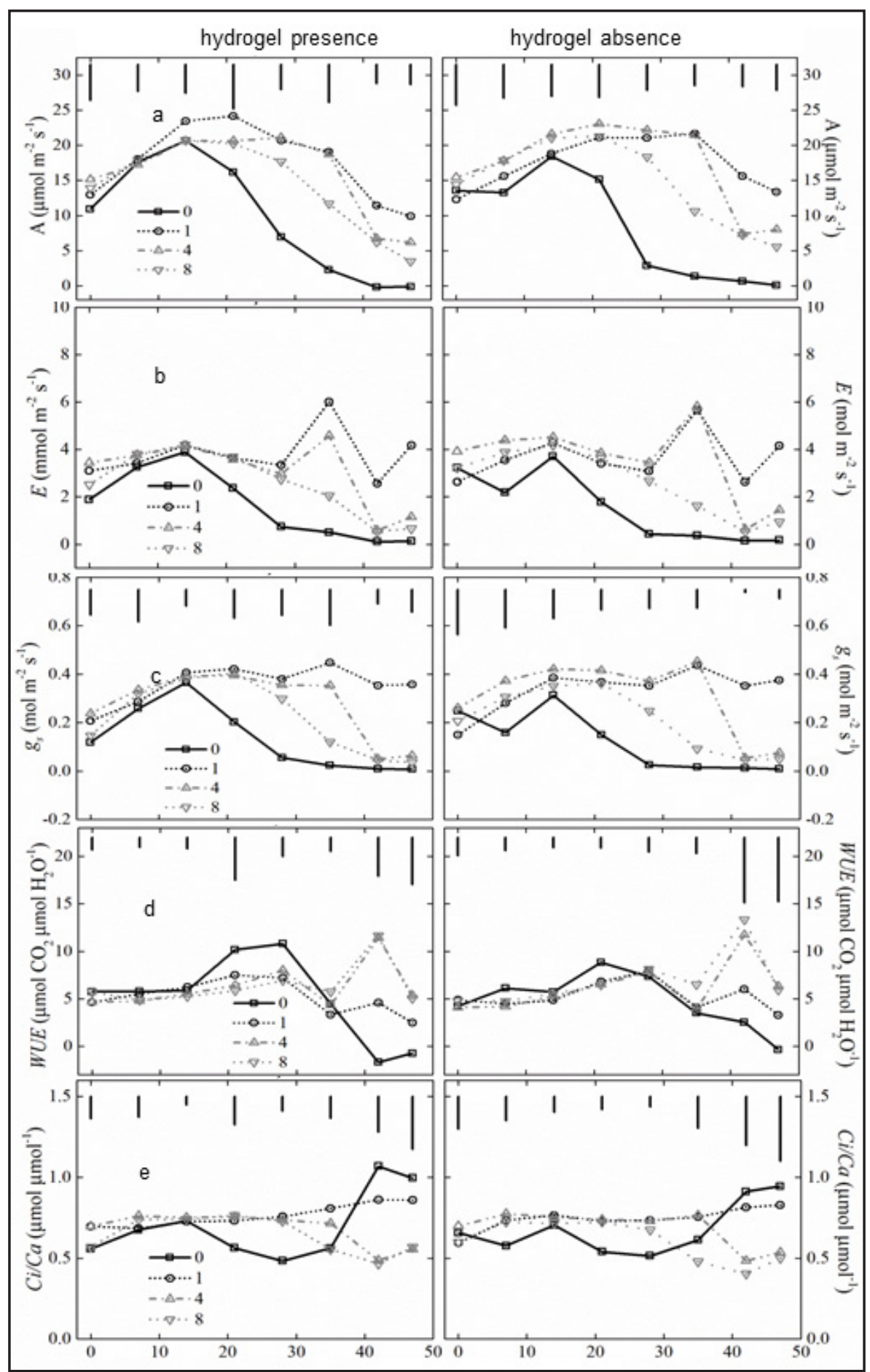

Source: Authors (2017)

In where: The floating bars indicate the minimum significant difference between the irrigation frequencies by the Scott-Knott's test $(p<0.05)$. 
For a general perspective of the relation between the intercellular and atmospheric concentrations of $\mathrm{CO}_{2}(\mathrm{Ci} / \mathrm{Ca})\left(\mathrm{\mu mol}^{-1} \mu \mathrm{mol}^{-1}\right)$, there was only difference between the highest frequencies and the lowest ones of irrigation (Figure 2e). Both in the presence and in absence of hydrogel the values increased due to the water deficit, especially when irrigation occurred at planting. At this frequency of irrigation, during 14 to 28 days, there was a decrease in the Ci/Ca. These values are justified due to the stomatal closure, which generally reduced the exchange of gases between the environment and the interior of the leaf, but there was still the assimilation of $\mathrm{CO}_{2}$ by the enzymes. From the $35^{\text {th }}$ day, there was an increase consequently to the enzymes, mainly rubisco, assimilating $\mathrm{CO}_{2}$. Thus, the limitation of $A$ ceased to be strictly stomatal and became biochemically.

The understanding of the factors influencing the physiological responses of Eucalyptus plantations can help in the planning and location of the plantations and the selection of genotypes, as well as in the choice of the appropriate management for plantations installed in environments with water restrictions. In addition, obtaining data on the photosynthetic capacity of plants is an important tool for models based on processes that require physiological information to predict the growth and use of water of different genotypes (OTTO et al., 2013).

\section{CONCLUSION}

The hydroretent polymer allowed the addition of approximately 5 days in the survival of Eucalyptus urograndis clones, providing an improvement in the morphological variables.

The hydrogel effect positively influenced the storage and availability of water to the plant in the soil, especially when the irrigations occurred less frequently.

The gas exchanges were affected by the soil water content, which varied according to the frequency of irrigation. The water deficit was a limiting factor for the stomatal opening and contributed to the decrease in carbon assimilation by photosynthesis, 
because of the lower was the water availability, the lower was the photosynthetic rate $(A)$, transpiration $(E)$ and stomatal conductance $(g)$ values. Furthermore, the water use efficiency (WUE) increased when the availability of water decreased.

\section{ACKNOWLEDGMENTS}

The authors would like to thank Research and Innovation Support Foundation of Santa Catarina State (FAPESC) for the scholarship awarded.

The authors pay tribute to the co-author of the article and Professor Clenilso Sehnen Mota, who died before the publication of the work. Professor Clenilso was a research enthusiast and a lover of plant physiology.

\section{REFERENCES}

AGABA, A. et al. Effects of hydrogel amendment to different soils on plant available water and survival of trees under drought conditions. Clean: Soil, Air, Water, Weinheim, v. 38, n. 4, p. 328-335, 2010.

ALVARES, C. A. et al. Köppen's climate classification map for Brazil. Meteorologische Zeitschrift, Stuttgart, v. 22, n. 6, p. 711-728, 2013.

BUZETTO, F. A.; BIZON, J. M. C.; SEIXAS, F. Avaliação de polímero adsorvente à base de acrilamida no fornecimento de água para mudas de Eucalyptus urophylla em pós-plantio. Circular Técnica IPEF, n. 195, p. 1-5, 2002. Disponível em: http://www.ipef.br/publicacoes/ctecnica/nr195.pdf. Acesso em: 15 abr. 2018.

CASAROLI, D.; VAN LIER, Q. J. Critérios para determinação da capacidade de vaso. Revista Brasileira de Ciência do Solo, Viçosa, MG, v. 32, p. 59-66, 2008.

CASTRO, V. R. et al. Efeito da disponibilidade hídrica e da aplicação de potássio e sódio no crescimento em diâmetro do tronco de árvores de Eucalyptus grandis. Scientia Forestalis, Piracicaba, v. 45, n. 113, p. 89-99, 2017.

CHAVES, J. H. et al. Seleção precoce de clones de eucalipto para ambientes com disponibilidade diferenciada de água no solo: relações hídricas de plantas em tubetes. Revista Árvore, Viçosa, MG, v. 28, n. 3, p. 333- 341, 2004.

FELIPPE, D. et al. Efeito do hidrogel no crescimento de mudas de Eucalyptus benthamii submetidas a diferentes frequências de irrigação. Floresta, Curitiba, v. 46, n. 2, p. 215-225, 2016. 
FERNÁNDEZ, M.; TAPIAS, R.; ALESSEO, P. Adaptación a la sequía y necesidades hídricas de Eucalyptus globulus Labill. en Huelva. Boletín del CIDEU, Huelva, v. 9, n. 8, p. 31-41, 2010.

FERREIRA, D. F. Sisvar: a computer analysis system to fixed effects split plot type designs. Revista Brasileira de Biometria, [s. I.], Lavras, v. 37, n. 4, p. 529-535, 2019.

GONÇALVES, M. R.; PASSOS, C. A. M. Crescimento de cinco espécies de eucalipto submetidas a déficit hídrico em dois níveis de fósforo. Ciência Florestal, Santa Maria, v. 10, n. 2, p. 145-161, 2000

INDÚSTRIA BRASILEIRA DE ÁRVORES. Indústria Brasileira de árvores: ano base 2017. Brasília, DF, 2017. 100 p.

KERBAUY, G. B. Fisiologia vegetal. Rio de Janeiro: Guanabara Koogan, 2009. 452 p.

KLIPPEL, V. H. et al. Impacto da deficiência hídrica no crescimento inicial de eucalipto. Revista Científica Eletrônica de Engenharia Florestal, [s. I.], v. 23, n. 1, p. 48-59, 2014.

LARCHER, W. Ecofisiologia vegetal. São Carlos: Rima, 2006. 531 p.

LAWLOR, D. W. Limitation to photosynthesis in water-stressed leaves: stomata vs. metabolism and the role of ATP. Annals of Botany, Oxford, v. 89, n. 7, p. 871-885, 2002.

LOPES, J. L. W. et al. Uso de hidrogel na sobrevivência de mudas de Eucalyptus urograndis produzidas com diferentes substratos e manejos hídricos. Ciência Florestal, Santa Maria, v. 20, n. 2, p. 217-224, 2010.

MENDONÇA, T.G. et al. Hidrogel como alternativa no aumento da capacidade de armazenamento de água no solo. Water Resources and Irrigation Management, Cruz das Almas, v. 2, p. 8792, 2013.

NASCIMENTO, S. P. D. et al. Tolerance to water déficit of cowpea genotypes. Revista Brasileira de Engenharia Agrícola e Ambiental, Campina Grande, v. 15, n. 8, p. 853-860, 2011.

NAVROSKI, M. C. et al. Influência do polímero hidroretentor na sobrevivência de mudas de Eucalyptus dunnii sob diferentes manejos hídricos. Revista Nativa, Sinop, v. 2, n. 2, p. 108-113, 2014.

NAVROSKI, M. C. et al. Redução da adubação e melhoria das características do substrato com o uso do hidrogel na produção de mudas de Eucalyptus dunnii Maiden. Ciência Florestal, Santa Maria, v. 26, n. 4, p. 1155-1165, 2016.

NAVROSKI, M. C. et al. Uso de hidrogel possibilita redução da irrigação e melhora o crescimento inicial de mudas de Eucalyptus. Scientia Forestalis, Piracicaba, v. 43, n. 106, p. 467-476, 2015.

NOGUEIRA, R. J. M. C.; ALBUQUERQUE, M. B.; SILVA, E. C. Aspectos ecofisiológicos da tolerância à seca em plantas da caatinga. In: NOGUEIRA, R. J. M. C. et al. Estresses ambientais: danos e benefícios em plantas. Recife: Universidade Federal de Pernambuco, 2005. p. 22-31.

OTTO, M. et al. Fotossíntese, condutância estomática e produtividade de clones de Eucalyptus sob diferentes condições edafoclimáticas. Revista Árvore, Viçosa, MG, v. 37, n. 3, p. 431-439, 2013. 
PFAUTSCH, S. et al. Climate determines vascular traits in the ecologically diverse genus Eucalyptus. Ecology Letters, Oxford, v. 19, n. 3, p. 240-248, 2016.

ZONTA, J. H. et al. influência de diferentes turnos de rega e doses de hidroabsorvente no desenvolvimento inicial da cultura do café conillon (Coffea canephora Pierre). Idesia, Arica, v. 27, n. 3, p. 29-34, 2009.

\section{Authorship Contribution}

\section{1 - Dionéia Felippe}

Forestry Engineer, MSc.

https://orcid.org/0000-0002-7211-8580•dioneia.felippe@gmail.com

Contribution: Investigation, Methodology, Software, Writing - original draft

\section{2 - Marcio Carlos Navroski}

Forestry Engineer, Professor

https://orcid.org/0000-0002-2645-9763 •marcio.navroski@udesc.br

Contribution: Conceptualization, Data curation, Funding acquisition,

Software, Supervision, Validation, Visualization, Writing - review \& editing

\section{3 - Jean Alberto Sampietro}

Forestry Engineer, Professor

https://orcid.org/0000-0001-6555-7166•jean.sampietro@udesc.br

Contribution: Conceptualization, Methodology, Supervision

\section{4 - Clenilso Sehnen Mota}

Agronomist, Professor

https://orcid.org/0000-0003-2483-1805•csm.sehnen@gmail.com

Contribution: Conceptualization, Data curation, Formal Analysis, Investigation, Methodology

\section{5 - Mariane de Oliveira Pereira}

Forestry Engineer, Dr.

https://orcid.org/0000-0001-5518-7464•maripereira.florestal@gmail.com

Contribution: Investigation, Writing - review \& editing 


\section{6 - Jackson Adriano Albuquerque}

Agronomist, Professor

https://orcid.org/0000-0002-7387-0336•jackson.albuquerque@udesc.br

Contribution: Conceptualization, Methodology

\section{7 - Ramon Silveira de Andrade}

Forestry Engineer, Master's student in Forestry Engineering https://orcid.org/0000-0001-6429-3947•ramon.andrade@edu.udesc.br

Contribution: Investigation, Writing - review \& editing

\section{8 - Carolina Moraes}

Forestry Engineer, Master's student in Forestry Engineering https://orcid.org/0000-0001-9936-1110 • carolina.moraes1@edu.udesc.br Contribution: Investigation, Visualization

\section{How to quote this article}

Felippe, D.; Navroski, M. C.; Sampietro, J. A.; Mota, C. S.; Pereira, M. O.; Albuquerque, J. A.; Andrade, R. S.; Moraes, C. Hydrogel and irrigation frequencies in survival, growth and gas exchanges in Eucalyptus urograndis. Ciência Florestal, Santa Maria, v. 31, n. 4, p. 1569-1590, 2021. DOI 10.5902/1980509836889. Available from: https://doi.org/10.5902/1980509836889. 